\title{
An Automated Approach for the Identification of Functionally-Relevant Small Molecule Inhibitors
}

D.M. Wilson

February 16, 2000

U.S. Department of Energy

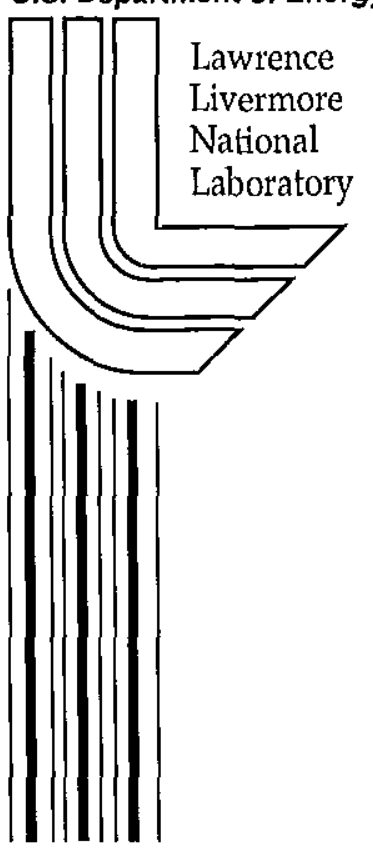





\section{DISCLAIMER}

This document was prepared as an account of work sponsored by an agency of the United States Government. Neither the United States Government nor the University of California nor any of their employees, makes any warranty, express or implied, or assumes any legal liability or responsibility for the accuracy, completeness, or usefulness of any information, apparatus, product, or process disclosed, or represents that its use would not infringe privately owned rights. Reference herein to any specific commercial product, process, or service by trade name, trademark, manufacturer, or otherwise, does not necessarily constitute or imply its endorsement, recommendation, or favoring by the United States Government or the University of California. The views and opinions of authors expressed herein do not necessarily state or reflect those of the United States Government or the University of California, and shall not be used for advertising or product endorsement purposes.

This work was performed under the auspices of the U. S. Department of Energy by the University of California, Lawrence Livermore National Laboratory under Contract No. W-7405-Eng-48.

This report has been reproduced directly from the best available copy.

Available electronically at http://www.doe.gov/bridge

Available for a processing fee to U.S. Department of Energy

and its contractors in paper from

U.S. Department of Energy

Office of Scientific and Technical Information

P.O. Box 62

Oak Ridge, TN 37831-0062

Telephone: (865) 576-8401

Facsimile: (865) 576-5728

E-mail: reports@adonis.osti.gov

Available for the sale to the public from

U.S. Department of Commerce

National Technical Information Service 5285 Port Royal Road Springfield, VA 22161

Telephone: (800) 553-6847

Facsimile: (703) 605-6900

E-mail: orders@ntis.fedworld.gov

Online ordering: http://www.ntis.gov/ordering.htm

OR

Lawrence Livermore National Laboratory

Technical Information Department's Digital Library

http://www.llnl.gov/tid/Library.html 

An automated approach for the identification of functionally-relevant small molecule inhibitors

PI: David M. Wilson III

Molecular \& Structural Biology Division

Biology \& Biotechnology Research Program, L-441

Lawrence Livermore National Laboratory

7000 East Avenue

Livermore, CA 94551

Purpose: Radiation induces the formation of DNA damages via direct ionization or through the production of reactive oxygen intermediates that chemically modify DNA. Radiation is thought to elicit its cytotoxicity by inducing the formation of lethal DNA damage, including modified bases, baseless sites and strand breaks. To avert the deleterious effects of radiation and chromosomal modifications, cells are equipped with DNA repair systems and cellular responses that function to amend genetic imperfections and to prevent the replication of damaged DNA. The focus of this proposal is to develop a novel, function-based technology for isolating inhibitors of proteins involved in radiation-protection. Such inhibitor molecules represent potential radiosensitizing agents, which could be used to increase the biological effectiveness of a given radiation dose in anti-cancer treatment schemes.

Approach: This project combines unique laboratory expertise in robotics, computational modeling, combinatorial chemistry, and DNA repair enzymology from the Biology \& Biotechnology Research Program and the Chemistry and Material Science Directorate. The screening technique will utilize a simple flow-based filter system operated by robotics. Commercial laboratory instrumentation and automation are available for creating a nearly hands-off system for inhibitor molecule screening. Specifically, a general purpose dispensing instrument (i.e. the Packard Multiprobe II), using opaque, filter-backed microtiter plates, will be combined with on-deck vacuum extraction to generate a rapid screening technology. System integration tools and experience from the LLNL Human Genome Project will be leveraged. This screening capability will be applied to current lab research on proteins involved in the repair of radiation damaged DNA. Inhibitors of proteins involved in cellular resistance to radiation have potential value as co-therapeutics in anti-cancer treatments and would be licensed to pharmaceutical companies for further testing. The developed technology can also potentially be used to determine the functions of new proteins identified during the Human Genome Project. An invention disclosure has been filed for the base technology to be designed.

Technical Accomplishments: Two major repair pathways, Base Excision Repair (BER) and Recombinational Repair (RR), exist to avert the deleterious effects of radiationinduce DNA damage. In the development of an automated system, we will identify inhibitor molecules for two proteins that participate in such pathways, namely the Ape1 protein (the major human abasic endonuclease of BER) and Fenl (a structure-specific endonuclease of RR). Since our experimentation revolves around isolating molecules 
that inhibit biochemical function (i.e. molecules that prevent DNA binding, polymerization or nuclease activity), we will in essence be identifying functionallyrelevant inhibitors.

In collaboration with the computational biochemistry group in BBRP, we have identified potential inhibitor molecules for Ape 1 using a "docking" approach (in which candidate ligands are examined for their fit into surface cavities of a known protein structure). These and related approaches provide a valuable pre-screen for experimental assays. A similar approach is underway for Fen 1. Potential inhibitors (which can be purchased or synthesized) identified by such docking methods will serve as the initial targets in our search for effective inhibitor compounds. Inhibitor screens are currently being performed for Ape1. Computational approaches will also be used in follow-up studies to determine the binding sites of the chemical inhibitors, to develop more potent inhibitors, and to draw predictive conclusions about the structure-function mechanism of the target protein. These studies are in the initial stages of development. 